\title{
Transformation sequence and second phases in ternary Ti-Ni-W shape memory alloys with less than 2 at.\% W
}

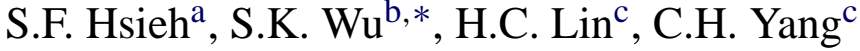

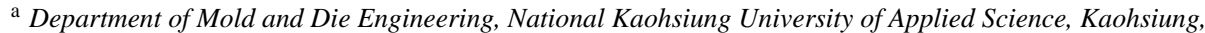 \\ Taiwan 807, Republic of China \\ ${ }^{\mathrm{b}}$ Department of Materials Science and Engineering, National Taiwan University, Taipei, \\ Taiwan 106, Republic of China \\ ${ }^{c}$ Department of Materials Science, Feng Chia University, Taichung, Taiwan, Republic of China
}

Received 10 May 2004; received in revised form 2 June 2004; accepted 2 June 2004

\begin{abstract}
Transformation sequence and second phases in $\mathrm{Ti}_{50-X} \mathrm{Ni}_{50} \mathrm{~W}_{X}, \mathrm{Ti}_{50} \mathrm{Ni}_{50-X} \mathrm{~W}_{X}$ and $\mathrm{Ti}_{51} \mathrm{Ni}_{49-X} \mathrm{~W}_{X}$ alloys with $X=1-2$ at. $\%$ are investigated. Two different second-phase particles located at grain boundaries are observed. The lattice parameters of $\mathrm{Ti}_{50} \mathrm{Ni}_{49} \mathrm{~W}_{1}$ martensite are calculated from the selected area diffraction patterns (SADP) and all of them are larger than those of $\mathrm{Ti}_{50} \mathrm{Ni}_{50}$ alloy. Experimental results indicate that the $\mathrm{W}$ atoms replace $\mathrm{Ni}$ atoms, instead of $\mathrm{Ti}$ ones in these alloys. In addition, $\mathrm{Ti}_{50-X} \mathrm{Ni}_{50} \mathrm{~W}_{X}$ and $\mathrm{Ti}_{51} \mathrm{Ni}_{49-X} \mathrm{~W}_{X}$ alloys have a two-stage $\mathrm{B} 2 \rightarrow$ $\mathrm{R} \rightarrow \mathrm{B} 19^{\prime}$ transformation, but the $\mathrm{Ti}_{50} \mathrm{Ni}_{50-X} \mathrm{~W}_{X}$ alloy has a one-stage B2 $\rightarrow$ B19' transformation because the former Ms temperatures are depressed significantly. The shape recovery of these alloys can be improved by the W solid-solution hardening. With higher matrix hardness in these alloys, there is better shape recovery.
\end{abstract}

(C) 2004 Elsevier B.V. All rights reserved.

Keywords: Ti-Ni-W shape memory alloys; Transformation sequence; Second phases; Shape recovery; Lattice parameters

\section{Introduction}

TiNi alloys are known as the most important shape memory alloys (SMAs) because of their superior properties in shape memory effect (SME) and pseudoelasticity (PE). This comes from the fact that TiNi alloys have very good ductility, strength, fatigue and corrosion resistance, recoverable strain, etc. It has been confirmed that TiNi SMA properties can be affected by various thermal-mechanical treatments, such as thermal cycling [1], aging treatment in Ni-rich alloys [2,3] and cold rolling [4]. Furthermore, the addition of a third element to replace $\mathrm{Ni}$ and/or Ti has a substantial effect on phase transformation behavior in TiNi alloys. The starting temperature of the martensitic transformation, Ms, of TiNi al-

\footnotetext{
* Corresponding author. Tel.: +886-2-23637846; fax: +886-2-23634562.

E-mail address: skw@ccms.ntu.edu.tw (S.K.Wu).
}

loys decreases following the substitution of $\mathrm{Ni}$ with $\mathrm{V}, \mathrm{Mn}$, $\mathrm{Fe}$ or Co [5-7], but increases remarkably following the substitution of $\mathrm{Ni}$ with $\mathrm{Au}, \mathrm{Pd}$ and $\mathrm{Pt}$ in amounts not less than 15-20 at.\% [8-10]. The two-stage martensitic transformation appears for some TiNiX ternary alloys, for example, B2 $\rightarrow \mathrm{R}$ $\rightarrow \mathrm{B} 19^{\prime}$ for $\mathrm{Ti}_{50} \mathrm{Ni}_{47} \mathrm{Fe}_{3}$ alloy [7], but $\mathrm{B} 2 \rightarrow \mathrm{B} 19 \rightarrow \mathrm{B} 19^{\prime}$ for $\mathrm{Ti}_{50} \mathrm{Ni}_{40} \mathrm{Cu}_{10}$ alloy $[11,12]$. Here, $\mathrm{B} 2$ is the parent austenite, $\mathrm{B} 19^{\prime}$ is the monoclinic martensite, $\mathrm{R}$ and $\mathrm{B} 19$ are the rhombohedral and orthorhombic premartensite, respectively. On the other hand, the addition of $\mathrm{Nb}$ in TiNi alloy can widen the transformation hysteresis to above $130^{\circ} \mathrm{C}$ and hence, extend the applications of coupling and sealing [13].

It is well known that a small deviation from stoichiometry in TiNi SMAs can give rise to significant precipitation of second phases $[14,15]$. This in turn affects both the alloy's strength and its shape memory effect. To our knowledge, the transformation behaviors and precipitated second phases of Ti-Ni-W ternary alloys with small amounts of $\mathrm{W}$ have 
been seldom reported [16]. The purpose of the present paper is to investigate the effect of substituted $\mathrm{W}$ on martensitic transformation sequence and precipitated second phases of $\mathrm{Ti}_{50-X} \mathrm{Ni}_{50} \mathrm{~W}_{X}, \mathrm{Ti}_{50} \mathrm{Ni}_{50-X} \mathrm{~W}_{X}$ and $\mathrm{Ti}_{51} \mathrm{Ni}_{49-X} \mathrm{~W}_{X}$ alloys with $X=1-2$ at.\%. The shape memory effect of these alloys is also briefly discussed.

\section{Experimental procedure}

The conventional tungsten arc melting technique was employed to prepare $\mathrm{Ti}_{50-} \mathrm{Ni}_{50} \mathrm{~W}_{X}, \mathrm{Ti}_{50} \mathrm{Ni}_{50-X} \mathrm{~W}_{X}$ and $\mathrm{Ti}_{51} \mathrm{Ni}_{49-X} \mathrm{~W}_{X}$ alloys with $X=1-2$ at.\%, i.e. $\mathrm{Ti}_{49} \mathrm{Ni}_{50} \mathrm{~W}_{1}$, $\mathrm{Ti}_{48} \mathrm{Ni}_{50} \mathrm{~W}_{2}, \mathrm{Ti}_{50} \mathrm{Ni}_{49} \mathrm{~W}_{1}, \mathrm{Ti}_{50} \mathrm{Ni}_{48} \mathrm{~W}_{2}, \mathrm{Ti}_{51} \mathrm{Ni}_{48} \mathrm{~W}_{1}$ and $\mathrm{Ti}_{51} \mathrm{Ni}_{47} \mathrm{~W}_{2}$ alloys (in atomic percent). In order to effectively introduce $\mathrm{W}$ into TiNi, a mother alloy of $\mathrm{Ni} 10 \mathrm{wt} . \% \mathrm{~W}$ was prepared. Titanium (purity $99.7 \mathrm{wt} . \%$ ), nickel (purity 99.9 wt.\%) and tungsten in the mother alloy, totalling about $120 \mathrm{~g}$, were melted and remelted at least six times in an argon atmosphere. A pure titanium button was also melted and used as a getter. The as-melted buttons were homogenized at $950{ }^{\circ} \mathrm{C}$ for $72 \mathrm{~h}$ and then quenched in water. The buttons were cut into several plates with a low speed diamond saw, sealed in evacuated quartz tubes, annealed at $900^{\circ} \mathrm{C} \times 2 \mathrm{~h}$ and quenched in water. DSC measurements were made with a Dupont 2000 thermal analyzer equipped with a quantitative scanning system 910 DSC cell for controlled heating and cooling runs on sample encapsulated in an aluminum pan. The running temperature range was from $-150^{\circ} \mathrm{C}$ to $250^{\circ} \mathrm{C}$ with a heating and cooling rate of $10^{\circ} \mathrm{C} / \mathrm{min}$. A quantitative analysis of the alloys, composition was performed by using a JOEL JXA-8900R electron probe microanalyzer (EPMA) equipped with a wavelength dispersive X-ray spectrometer (WDS) analysis system. The operating voltage of EPMA was $20 \mathrm{kV}$ and the software for quantification was the XM-97312 quantitative analysis program. The shape memory effect was examined by a bending test, as illustrated in a previous paper [17]. Microstructure observations were made by transmission electron microscopy (TEM) with a PHILIPS-CM200 microscope equipped with a conventional double-tilting stage. The TEM specimens were prepared by electropolishing at $-10{ }^{\circ} \mathrm{C}$ with an electrolyte consisting of $20 \% \mathrm{H}_{2} \mathrm{SO}_{4}$ and $80 \% \mathrm{CH}_{3} \mathrm{OH}$ by volume. The applied voltage for electropolishing was $20 \mathrm{~V}$.

\section{Results and discussion}

\subsection{Second phases and martensite in Ti-Ni-W alloys}

Fig. 1a-f show the EPMA back-scattering electron images (BEIs) of homogenized $\mathrm{Ti}_{49} \mathrm{Ni}_{50} \mathrm{~W}_{1}, \mathrm{Ti}_{48} \mathrm{Ni}_{50} \mathrm{~W}_{2}$, $\mathrm{Ti}_{50} \mathrm{Ni}_{49} \mathrm{~W}_{1}, \mathrm{Ti}_{50} \mathrm{Ni}_{48} \mathrm{~W}_{2}, \mathrm{Ti}_{51} \mathrm{Ni}_{48} \mathrm{~W}_{1}$ and $\mathrm{Ti}_{51} \mathrm{Ni}_{47} \mathrm{~W}_{2}$ alloys, respectively. There are three different contrast areas that can be observed in $\mathrm{Ti}_{50} \mathrm{Ni}_{49} \mathrm{~W}_{1}, \mathrm{Ti}_{50} \mathrm{Ni}_{48} \mathrm{~W}_{2}, \mathrm{Ti}_{51} \mathrm{Ni}_{48} \mathrm{~W}_{1}$ and $\mathrm{Ti}_{51} \mathrm{Ni}_{47} \mathrm{~W}_{2}$ alloys, including the gray matrix, the black particles and the white particles, as shown in Fig. 1c-f. Only gray matrix and white particles located around grain boundaries appear in Fig. $1 \mathrm{a}$ and $\mathrm{b}$ of $\mathrm{Ti}_{49} \mathrm{Ni}_{50} \mathrm{~W}_{1}$ and $\mathrm{Ti}_{48} \mathrm{Ni}_{50} \mathrm{~W}_{2}$ alloys, respectively. Chemical compositions of the matrix and second-phase particles determined by EPMA are given in Table 1. The data shown in Table 1 are the averages taken of at least five tests for each area. The atomic ratios $r=$ $\mathrm{Ti} /(\mathrm{Ni}+\mathrm{W})$ for the matrix and black particles are also calculated in Table 1 . Based on the $1227^{\circ} \mathrm{C}$ Ti-Ni-W ternary phase diagram [18] and backscattering electron characteristics of EPMA image, Table 1 indicates that all the matrix in Fig. 1 is TiNi SMA containing a little $\mathrm{W}$ in solid solution. The amount of $\mathrm{W}$ atoms in the solid solution of the TiNi matrix increases slightly with an increase in the $\mathrm{W}$ content in Ti-Ni-W SMAs. The black particles are the $\mathrm{Ti}_{2}(\mathrm{Ni}, \mathrm{W})$ phase in $\mathrm{Ti}_{50} \mathrm{Ni}_{50-} \mathrm{W}_{X}, \mathrm{Ti}_{51} \mathrm{Ni}_{50-X} \mathrm{~W}_{X}$ alloys with $X=1$ and 2 at.\%. All the white particles in Fig. 1 are the W-rich solid solution (W-s), in which large amounts of Ti and Ni can be accommodated. According to the $\boldsymbol{r}$ ratios of the matrix and black particles shown in Table 1, the $\mathrm{W}$ atoms in Ti-Ni-W SMAs are proposed to substitute into Ni atomic sites, instead of Ti sites. This characteristic is discussed further below.

Fig. 2a shows the TEM bright field image of martensite in an as-annealed $\mathrm{Ti}_{50} \mathrm{Ni}_{49} \mathrm{~W}_{1}$ alloy. Fig. $2 \mathrm{~b}-\mathrm{d}$ are the selected area diffraction patterns (SADPs) of this alloy, in which the foil is parallel to the $\left[\begin{array}{lll}1 & 0 & 0\end{array}\right]_{\mathrm{M}},\left[\begin{array}{lll}0 & 1 & 0\end{array}\right]_{\mathrm{M}}$ and $\left[\begin{array}{llll}0 & 0 & 1\end{array}\right]_{\mathrm{M}}$ direction, respectively. From the SADPs of Fig. 2b-c, the lattice parameters of martensite in $\mathrm{Ti}_{50} \mathrm{Ni}_{49} \mathrm{~W}_{1}$ alloy can be calculated as a monoclinic structure with $a=0.301 \mathrm{~nm}, b=0.423 \mathrm{~nm}, c$ $=0.472 \mathrm{~nm}$ and $\beta=97.5^{\circ}$. These parameters are all larger than those of the binary $\mathrm{Ti}_{50} \mathrm{Ni}_{50}$ alloy $(a=0.2889 \mathrm{~nm}, b=$ $0.4120 \mathrm{~nm}, c=0.4622 \mathrm{~nm}$ and $\beta=96.8^{\circ}$ [19]). Bricknell et al. [20] reported that the factors affecting the crystal structure stability and the Ms transformation temperature in $\mathrm{Ti}-\mathrm{Ni}-\mathrm{Cu}$ SMAs are atomic size, relative ionic size, electronegativity and density of state at the Fermi level. The same phenomena may occur in $\mathrm{Ti}_{50} \mathrm{Ni}_{49} \mathrm{~W}_{1}$ alloy. Table 2 shows the values of the relevant parameters for the three elements involved in this study [21]. In Table 2, W is larger than Ni but less than $\mathrm{Ti}$ in atomic size. W has also the electronegativity which is higher than Ni but is much higher than Ti. From the viewpoint of comparable electronegativity, $\mathrm{W}$ atoms in $\mathrm{Ti}-\mathrm{Ni}-\mathrm{W}$ SMAs should replace Ni atomic sites, instead of Ti ones. This characteristic is further confirmed by the fact that the lattice parameters of martensite in $\mathrm{Ti}_{50} \mathrm{Ni}_{49} \mathrm{~W}_{1}$ alloy of Fig. 2 are all larger than those in equiatomic TiNi alloy because the smaller $\mathrm{Ni}$ atoms are replaced by the larger $\mathrm{W}$ ones in this alloy.

\subsection{Transformation sequence in $\mathrm{Ti}-\mathrm{Ni}-\mathrm{W}$ alloys}

Fig. 3a-1 show the experimental results of DSC measurements for the annealed $\mathrm{Ti}_{49} \mathrm{Ni}_{50} \mathrm{~W}_{1}, \mathrm{Ti}_{48} \mathrm{Ni}_{50} \mathrm{~W}_{2}$, $\mathrm{Ti}_{50} \mathrm{Ni}_{49} \mathrm{~W}_{1}, \mathrm{Ti}_{50} \mathrm{Ni}_{48} \mathrm{~W}_{2}, \mathrm{Ti}_{51} \mathrm{Ni}_{48} \mathrm{~W}_{1}$ and $\mathrm{Ti}_{51} \mathrm{Ni}_{47} \mathrm{~W}_{2}$ alloys on cooling (Fig. 3a-f) and heating (Fig. 3g-1) cycles. The peaks $\mathrm{M}^{*}$ and $\mathrm{A}^{*}$ (including $\mathrm{Ms}$ and As temperatures) 

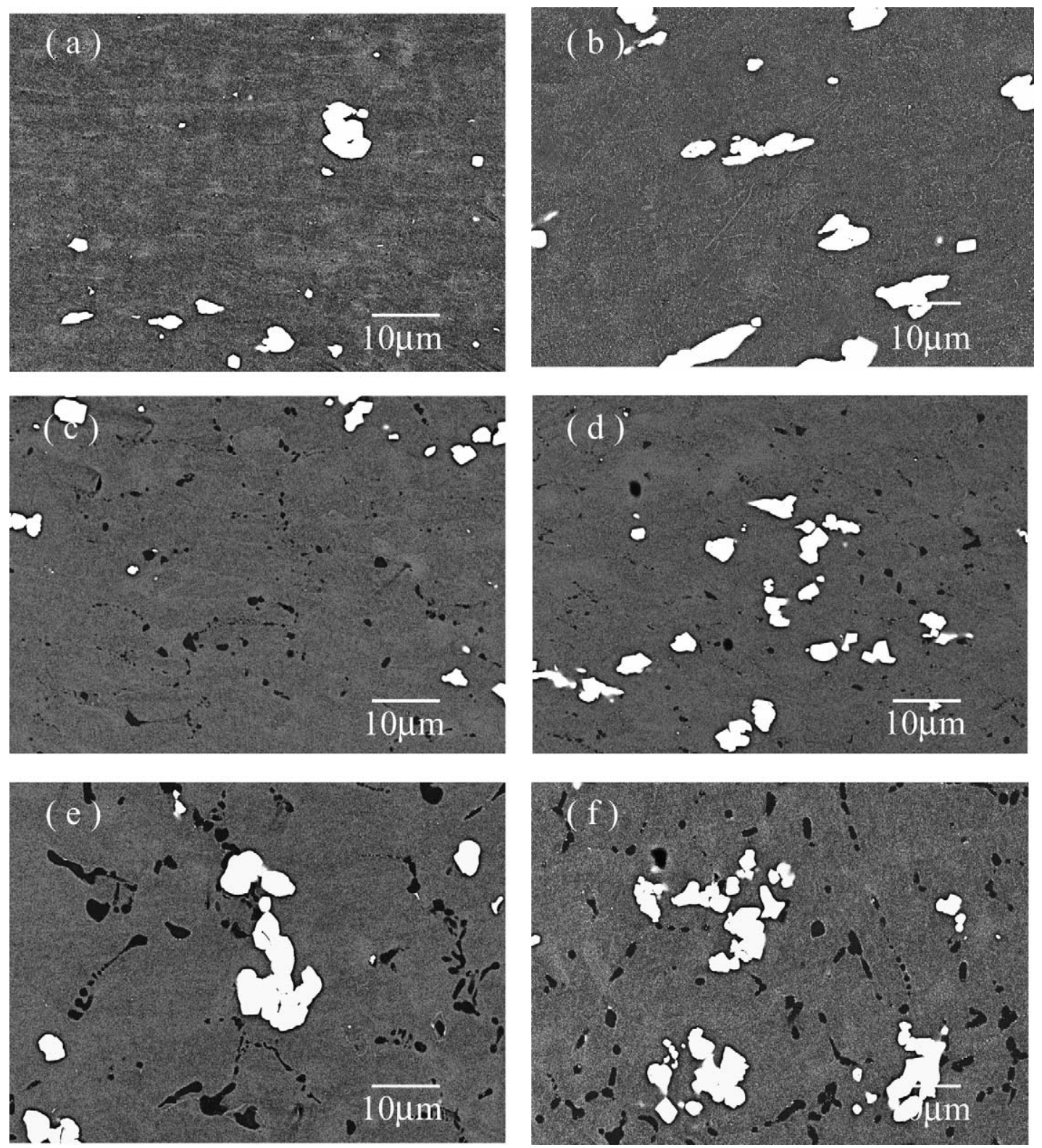

Fig. 1. The EPMA back-scattering electron images (BEIs) of the $950{ }^{\circ} \mathrm{C} \times 72 \mathrm{~h}$ homogenized (a) $\mathrm{Ti}_{49} \mathrm{Ni}_{50} \mathrm{~W}_{1}$, (b) $\mathrm{Ti}_{48} \mathrm{Ni}_{50} \mathrm{~W}_{2}$, (c) $\mathrm{Ti}_{50} \mathrm{Ni}_{49} \mathrm{~W}_{1}$, (d) $\mathrm{Ti}_{50} \mathrm{Ni}_{48} \mathrm{~W}_{2}$, (e) $\mathrm{Ti}_{51} \mathrm{Ni}_{48} \mathrm{~W}_{1}$ and (f) $\mathrm{Ti}_{51} \mathrm{Ni}_{47} \mathrm{~W}_{2}$ alloys.

appearing in Fig. 3 are associated with the forward and reverse martensitic transformation, respectively. Fig. 3c, d, i and $\mathrm{j}$ for $\mathrm{Ti}_{50} \mathrm{Ni}_{49} \mathrm{~W}_{1}$ and $\mathrm{Ti}_{50} \mathrm{Ni}_{48} \mathrm{~W}_{2}$ alloys each exhibit a single exothermic and endothermic peak, respectively, on each cooling and heating curve. Fig. 3a, b, e-h, k and 1 for $\mathrm{Ti}_{49} \mathrm{Ni}_{50} \mathrm{~W}_{1}, \mathrm{Ti}_{48} \mathrm{Ni}_{50} \mathrm{~W}_{2}, \mathrm{Ti}_{51} \mathrm{Ni}_{48} \mathrm{~W}_{1}$ and $\mathrm{Ti}_{51} \mathrm{Ni}_{47} \mathrm{~W}_{2}$ alloys, respectively, show double DSC peaks appearing on the cooling curve, but only one DSC peak on the heating curve. The single DSC peak occurring in Fig. $3 \mathrm{c}$ and dindicates that it is the $\mathrm{B} 2 \rightarrow{\mathrm{B} 19^{\prime}}^{\prime}$ one-stage martensitic transformation. Double DSC peaks appearing in Fig. 3a, b, e and $f$ are associated with the $\mathrm{B} 2 \rightarrow \mathrm{R} \rightarrow \mathrm{B} 19^{\prime}$ two-stage martensitic transformation. Here $\mathrm{R}$ is the rhombohedral premartensite phase. The results of Fig. 3 demonstrate that the transformation se- quences of annealed Ti-Ni-W SMAs can be divided into two groups, the one-stage $\mathrm{B} 2 \rightarrow \mathrm{B}^{\prime} 9^{\prime}$ transformation appearing in Ti-Ni-W SMAs with the matrix having $\boldsymbol{r} \approx 1.0$, and the two-stage $\mathrm{B} 2 \rightarrow \mathrm{R} \rightarrow \mathrm{B} 19^{\prime}$ transformation with the matrix having $\boldsymbol{r}>1.0$ or $\boldsymbol{r}<1.0$. Here $\boldsymbol{r}$ is the atomic ratio of Ti/(Ni $+\mathrm{W}$ ), as defined in Section 3.1. The former group includes $\mathrm{Ti}_{50} \mathrm{Ni}_{49} \mathrm{~W}_{1}$ and $\mathrm{Ti}_{50} \mathrm{Ni}_{48} \mathrm{~W}_{2}$ alloys, which can be regarded as the equivalent of $\mathrm{Ti}_{50} \mathrm{Ni}_{50}$ SMA since $\mathrm{W}$ atoms occupy $\mathrm{Ni}$ atomic sites in these alloys. From the same viewpoint, the latter group includes the Ti-rich Ti-Ni-W SMAs $\left(\mathrm{Ti}_{51} \mathrm{Ni}_{48} \mathrm{~W}_{1}\right.$ and $\mathrm{Ti}_{51} \mathrm{Ni}_{47} \mathrm{~W}_{2}$ alloys) and $\mathrm{Ni}$-rich ones $\left(\mathrm{Ti}_{49} \mathrm{Ni}_{50} \mathrm{~W}_{1}\right.$ and $\mathrm{Ti}_{48} \mathrm{Ni}_{50} \mathrm{~W}_{2}$ alloys).

From Fig. 3, all DSC results of $\mathrm{M}^{*}(\mathrm{Ms}), \mathrm{R}^{*}$ and $\mathrm{A}^{*}$ temperatures are listed in Table 3. Specimen hardnesses, Hv, 
Table 1

Compositional analyses by EPMA of $\mathrm{Ti}_{50-X} \mathrm{Ni}_{50} \mathrm{~W}_{X}, \mathrm{~T}_{50} \mathrm{Ni}_{50-X} \mathrm{~W}_{X}$ and $\mathrm{Ti}_{51} \mathrm{Ni}_{49-X} \mathrm{~W}_{X}$ alloys with $X=1$ and 2 at.\% homogenized at $950{ }^{\circ} \mathrm{C}$ for $72 \mathrm{~h}$

\begin{tabular}{|c|c|c|c|c|c|}
\hline & $\mathrm{Ti}($ at. \%) & $\mathrm{Ni}($ at.\%) & $\mathrm{W}($ at. $\%)$ & $\mathrm{Ti} /(\mathrm{Ni}+\mathrm{W}) \boldsymbol{r}$ ratio & Remark \\
\hline \multicolumn{6}{|c|}{$950^{\circ} \mathrm{C} \times 72 \mathrm{~h}$ as quenched } \\
\hline \multicolumn{6}{|c|}{$\mathrm{Ti}_{49} \mathrm{Ni}_{50} \mathrm{~W}_{1}$} \\
\hline M & $49.26 \pm 0.15$ & $50.45 \pm 0.18$ & $0.29 \pm 0.08$ & 0.971 & Matrix \\
\hline $\mathrm{W}$ & $10.25 \pm 1.47$ & $3.59 \pm 0.72$ & $86.16 \pm 2.54$ & - & W-s \\
\hline \multicolumn{6}{|c|}{$\mathrm{Ti}_{48} \mathrm{Ni}_{50} \mathrm{~W}_{2}$} \\
\hline M & $49.13 \pm 0.20$ & $50.54 \pm 0.20$ & $0.33 \pm 0.10$ & 0.966 & Matrix \\
\hline W & $9.60 \pm 1.32$ & $3.68 \pm 0.64$ & $86.72 \pm 2.36$ & - & W-s \\
\hline \multicolumn{6}{|c|}{$\mathrm{Ti}_{50} \mathrm{Ni}_{49} \mathrm{~W}_{1}$} \\
\hline M & $49.98 \pm 0.24$ & $49.71 \pm 0.20$ & $0.31 \pm 0.10$ & 0.999 & Matrix \\
\hline $\mathrm{W}$ & $15.17 \pm 1.02$ & $3.29 \pm 0.57$ & $81.54 \pm 1.32$ & - & W-s \\
\hline B & $66.76 \pm 0.25$ & $32.94 \pm 0.25$ & $0.30 \pm 0.07$ & 2.008 & $\mathrm{Ti}_{2}(\mathrm{Ni}, \mathrm{W})$ \\
\hline \multicolumn{6}{|c|}{$\mathrm{Ti}_{50} \mathrm{Ni}_{48} \mathrm{~W}_{2}$} \\
\hline M & $50.07 \pm 0.20$ & $49.55 \pm 0.26$ & $0.38 \pm 0.08$ & 1.003 & Matrix \\
\hline $\mathrm{W}$ & $14.49 \pm 1.38$ & $3.56 \pm 0.53$ & $81.95 \pm 1.21$ & - & W-s \\
\hline B & $67.05 \pm 0.20$ & $32.68 \pm 0.26$ & $0.27 \pm 0.07$ & 2.035 & $\mathrm{Ti}_{2}(\mathrm{Ni}, \mathrm{W})$ \\
\hline \multicolumn{6}{|c|}{$\mathrm{Ti}_{51} \mathrm{Ni}_{48} \mathrm{~W}_{1}$} \\
\hline M & $50.33 \pm 0.20$ & $49.32 \pm 0.20$ & $0.35 \pm 0.07$ & 1.013 & Matrix \\
\hline $\mathrm{W}$ & $14.26 \pm 1.32$ & $3.62 \pm 0.45$ & $82.12 \pm 1.13$ & & W-s \\
\hline B & $66.97 \pm 0.28$ & $32.71 \pm 0.24$ & $0.32 \pm 0.06$ & 2.028 & $\mathrm{Ti}_{2}(\mathrm{Ni}, \mathrm{W})$ \\
\hline \multicolumn{6}{|c|}{$\mathrm{Ti}_{51} \mathrm{Ni}_{47} \mathrm{~W}_{2}$} \\
\hline M & $50.46 \pm 0.18$ & $49.17 \pm 0.18$ & $0.37 \pm 0.06$ & 1.019 & Matrix \\
\hline $\mathrm{W}$ & $13.94 \pm 1.22$ & $3.53 \pm 0.48$ & $82.53 \pm 1.08$ & - & W-s \\
\hline B & $67.18 \pm 0.20$ & $32.53 \pm 0.25$ & $0.29 \pm 0.07$ & 2.047 & $\mathrm{Ti}_{2}(\mathrm{Ni}, \mathrm{W})$ \\
\hline
\end{tabular}

M: matrix; B: black particles; W: white particles (a tungsun-rich solid solution, W-s).

Table 2

Significant parameters of the metals species in this study [21]

\begin{tabular}{lllll}
\hline Element & Atomic radius $(\mathrm{nm})$ & Electronegativity & Valence state & Ionic radius $(\mathrm{nm})$ \\
\hline $\mathrm{Ti}$ & 0.147 & 1.54 & +2 & 0.076 \\
\\
$\mathrm{Ni}$ & & & +4 & 0.064 \\
$\mathrm{~W}$ & 0.125 & 1.91 & +2 & 0.078 \\
& 0.137 & 2.36 & +4 & +0.068 \\
\end{tabular}

including the matrix and second phase particles, are also shown in Table 3. From Table 3, transformation peak temperatures $\mathrm{M}^{*}, \mathrm{R}^{*}$ and $\mathrm{A}^{*}$ versus $\mathrm{W}$ content (at.\%) in Ti-Ni-W SMAs are plotted in Fig. 4. From Fig. 4, it is clear that the peak temperatures $A^{*}, R^{*}$ and $M^{*}$ decrease with increasing amounts of W in Ti-rich and Ni-rich Ti-Ni-W SMAs, but not in $\mathrm{Ti}_{50} \mathrm{Ni}_{50-X} \mathrm{~W}_{X}$ alloys (the equivalent $\mathrm{Ti}_{50} \mathrm{Ni}_{50} \mathrm{SMA}$ ). At the same time, the Ms temperature can be further depressed to induce the $\mathrm{R}$ phase by using small amounts of $\mathrm{W}$ in $\mathrm{Ni}$ - rich Ti-Ni-W SMAs, rather than in Ti-rich ones. Fig. 4 and Table 3 also show that transformation temperatures decrease, but the hardness increases, with increasing amounts of $\mathrm{W}$ in Ti-rich $\mathrm{Ti}_{51} \mathrm{Ni}_{49-X} \mathrm{~W}_{X}$ alloys and Ni-rich $\mathrm{Ti}_{50-} \mathrm{Ni}_{50} \mathrm{~W}_{X}$ alloys. This phenomenon also occurs in Ti-rich $\mathrm{Ti}_{52} \mathrm{Ni}_{47} \mathrm{Al}_{1}$ alloy [22], and can be ascribed to $\mathrm{W}$ solid-solution hardening. It is pointed out that any strengthening mechanism which can impede the transformation shear can lower the $\mathrm{Ms}\left(\mathrm{M}^{*}\right)$ transformation temperature because the martensite

Table 3

Peak temperatures and specimen hardnesses, including matrix and second phase particles, for $\mathrm{Ti}_{50-X} \mathrm{Ni}_{50} \mathrm{~W}_{X}, \mathrm{~T}_{50} \mathrm{Ni}_{50-X} \mathrm{~W}_{X}$ and $\mathrm{Ti}_{51} \mathrm{Ni}_{49-X} \mathrm{~W}_{X}$ alloys with $X=1$ and 2 at. $\%$

\begin{tabular}{|c|c|c|c|c|c|c|c|}
\hline & \multirow[t]{3}{*}{$\mathrm{M}^{*}\left({ }^{\circ} \mathrm{C}\right)$} & \multirow[t]{3}{*}{$\mathrm{Ms}\left({ }^{\circ} \mathrm{C}\right)$} & \multirow[t]{3}{*}{$\mathrm{R}^{*}\left({ }^{\circ} \mathrm{C}\right)$} & \multirow[t]{3}{*}{$\mathrm{A}^{*}\left({ }^{\circ} \mathrm{C}\right)$} & \multicolumn{3}{|c|}{ Vickers hardness (Hv) } \\
\hline & & & & & \multicolumn{2}{|c|}{ Matrix } & \multirow[t]{2}{*}{ Particles } \\
\hline & & & & & $27^{\circ} \mathrm{C}$ & $92^{\circ} \mathrm{C}$ & \\
\hline $\mathrm{Ti}_{49} \mathrm{Ni}_{50} \mathrm{~W}_{1}$ & -38 & -28 & -17 & -2 & 263 & 273 & 295 \\
\hline $\mathrm{Ti}_{48} \mathrm{Ni}_{50} \mathrm{~W}_{2}$ & -55 & -37 & -36 & -16 & 272 & 280 & 298 \\
\hline $\mathrm{Ti}_{50} \mathrm{Ni}_{49} \mathrm{~W}_{1}$ & 57 & 63 & - & 90 & 214 & - & 265 \\
\hline $\mathrm{Ti}_{50} \mathrm{Ni}_{48} \mathrm{~W}_{2}$ & 51 & 55 & - & 80 & 223 & - & 269 \\
\hline $\mathrm{Ti}_{51} \mathrm{Ni}_{48} \mathrm{~W}_{1}$ & 41 & 50 & 48 & 74 & 235 & 256 & 274 \\
\hline $\mathrm{Ti}_{51} \mathrm{Ni}_{47} \mathrm{~W}_{2}$ & 31 & 43 & 39 & 64 & 242 & 262 & 281 \\
\hline
\end{tabular}



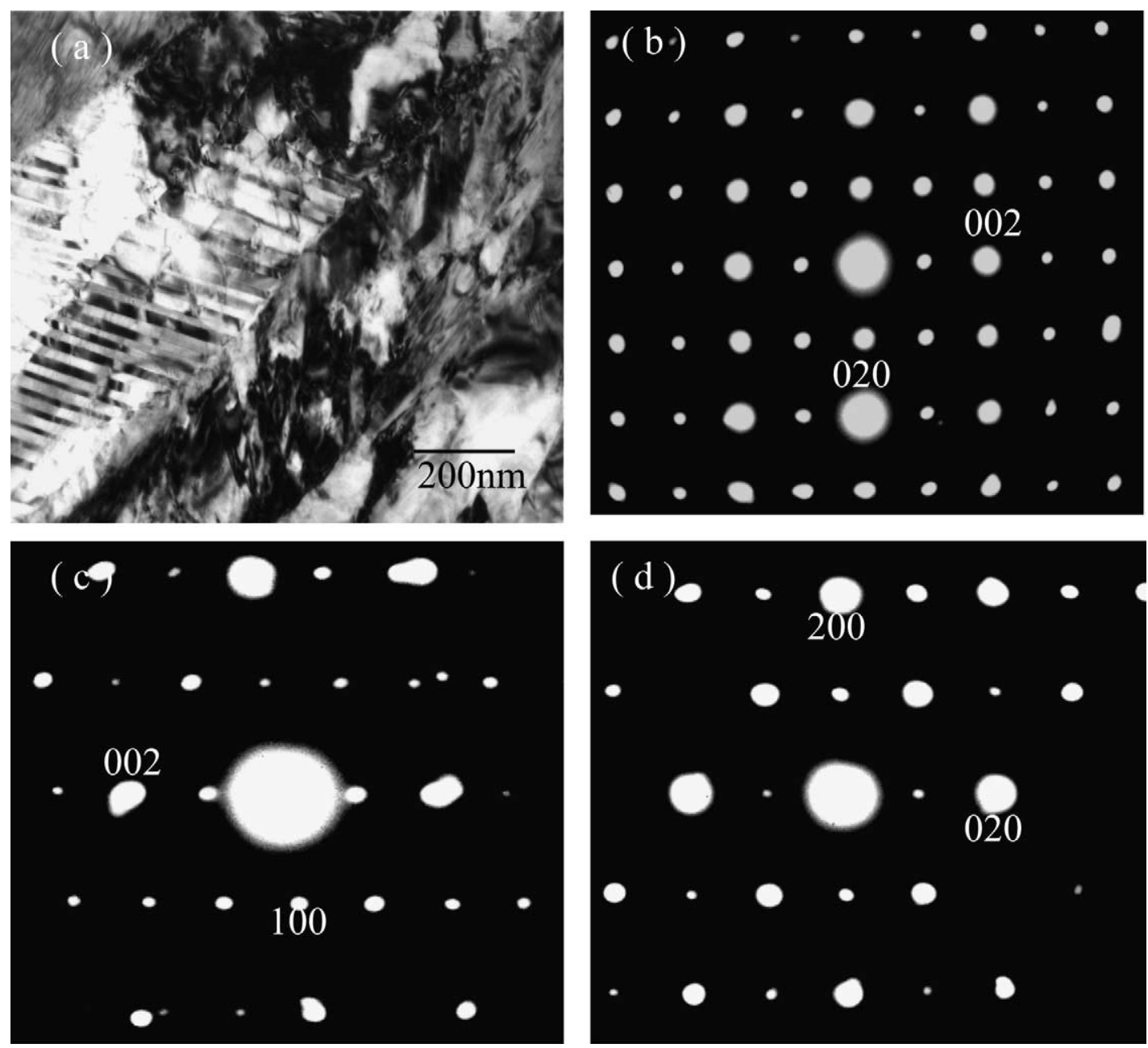

Fig. 2. (a) TEM bright-field image of the annealed $\mathrm{Ti}_{50} \mathrm{Ni}_{49} \mathrm{~W}_{1}$ alloy, (b) SADP of (a) with $\left[\begin{array}{lll}1 & 0 & 0\end{array}\right]_{\mathrm{M}}$ zone axis, (c) SADP of (a) with $[010]_{M}$ zone axis, (d) SADP of (a) with $\left[\begin{array}{lll}0 & 0 & 1\end{array}\right]_{\mathrm{M}}$ zone axis.

transformation involves a shear process [23-25]. Moreover, martensitic transformation can be retarded by the fine hard dispersed particles, which may result in transformation temperatures being much more depressed.

The $\boldsymbol{r}$ ratios of the matrix in $\mathrm{Ti}_{50} \mathrm{Ni}_{49} \mathrm{~W}_{1}$ and $\mathrm{Ti}_{50} \mathrm{Ni}_{48} \mathrm{~W}_{2}$ alloys are near 1.0, and their peak temperatures are almost the same as those of the equiatomic $\mathrm{Ti}_{50} \mathrm{Ni}_{50}$ alloy [4]. A similar result can also be found in a reported $\mathrm{Ti}_{50} \mathrm{Ni}_{49.5} \mathrm{~W}_{0.5}$ alloy (As $=97^{\circ} \mathrm{C}, A_{\mathrm{f}}=107^{\circ} \mathrm{C}, \mathrm{Ms}=65^{\circ} \mathrm{C}$ and $M_{\mathrm{f}}=33^{\circ} \mathrm{C}$ ) [16]. Fig. $1 \mathrm{c}$ and $\mathrm{d}$ show that there are many second phase particles around grain boundaries in $\mathrm{Ti}_{50} \mathrm{Ni}_{49} \mathrm{~W}_{1}$ and $\mathrm{Ti}_{50} \mathrm{Ni}_{48} \mathrm{~W}_{2}$ alloys. It is well known that $\mathrm{M} *(\mathrm{Ms})$ temperatures can be depressed due to the introduction of oxygen in the matrix of TiNi alloys [26]. But these oxygen atoms can be easily absorbed by the $\mathrm{Ti}_{2} \mathrm{Ni}$ phase to form the $\mathrm{Ti}_{4} \mathrm{Ni}_{2} \mathrm{O}$ oxide [15,27]. In $\mathrm{Ti}_{50} \mathrm{Ni}_{49} \mathrm{~W}_{1}$ and $\mathrm{Ti}_{50} \mathrm{Ni}_{48} \mathrm{~W}_{2}$ alloys, the oxygen atoms in the matrix can be absorbed by the $\mathrm{Ti}_{2}(\mathrm{Ni}, \mathrm{W})$ particles, and hence the oxygen content in the matrix can be reduced. This feature will contribute to raise transformation temperatures. However, the $\mathrm{W}$ dissolved in the TiNi matrix increases the hardness, which in turn depresses the transformation temperatures. These two compensation effects make that the transformation temperatures of $\mathrm{Ti}_{50} \mathrm{Ni}_{49} \mathrm{~W}_{1}$ and $\mathrm{Ti}_{50} \mathrm{Ni}_{48} \mathrm{~W}_{2}$ alloys are quite similar to those of $\mathrm{Ti}_{50} \mathrm{Ni}_{50}$ SMA.

\subsection{Shape recovery on $\mathrm{Ti}-\mathrm{Ni}-\mathrm{W}$ alloys}

The shape recovery was measured by bending tests. For this, the specimen is deformed in liquid nitrogen $\left(-196^{\circ} \mathrm{C}\right)$ for $\mathrm{Ti}_{49} \mathrm{Ni}_{50} \mathrm{~W}_{1}, \mathrm{Ti}_{48} \mathrm{Ni}_{50} \mathrm{~W}_{2}, \mathrm{Ti}_{51} \mathrm{Ni}_{48} \mathrm{~W}_{1}$ and $\mathrm{Ti}_{51} \mathrm{Ni}_{47} \mathrm{~W}_{2}$ alloys, respectively, and then is heated above the $A_{\mathrm{f}}$ temperature to complete the reverse martensitic transformation. Both $\mathrm{Ti}_{50} \mathrm{Ni}_{49} \mathrm{~W}_{1}$ and $\mathrm{Ti}_{50} \mathrm{Ni}_{48} \mathrm{~W}_{2}$ alloys have microstructures similar to $\mathrm{Ti}_{51} \mathrm{Ni}_{48} \mathrm{~W}_{1}$ and $\mathrm{Ti}_{51} \mathrm{Ni}_{47} \mathrm{~W}_{2}$ alloys, so bending tests are omitted for them. Table 4 presents the measured shape recovery at different bending strain, $\varepsilon_{\mathrm{S}}$, for the aforementioned specimens. The volume fraction of the second phase particles in these specimens is also shown in Table 4. Table 3 indicates that the hardness of these particles is greater than that of TiNi matrix. Tables 3 and 4 show that the shape recovery is a function of the matrix hardness, bending strain and second phase volume. The shape recovery 


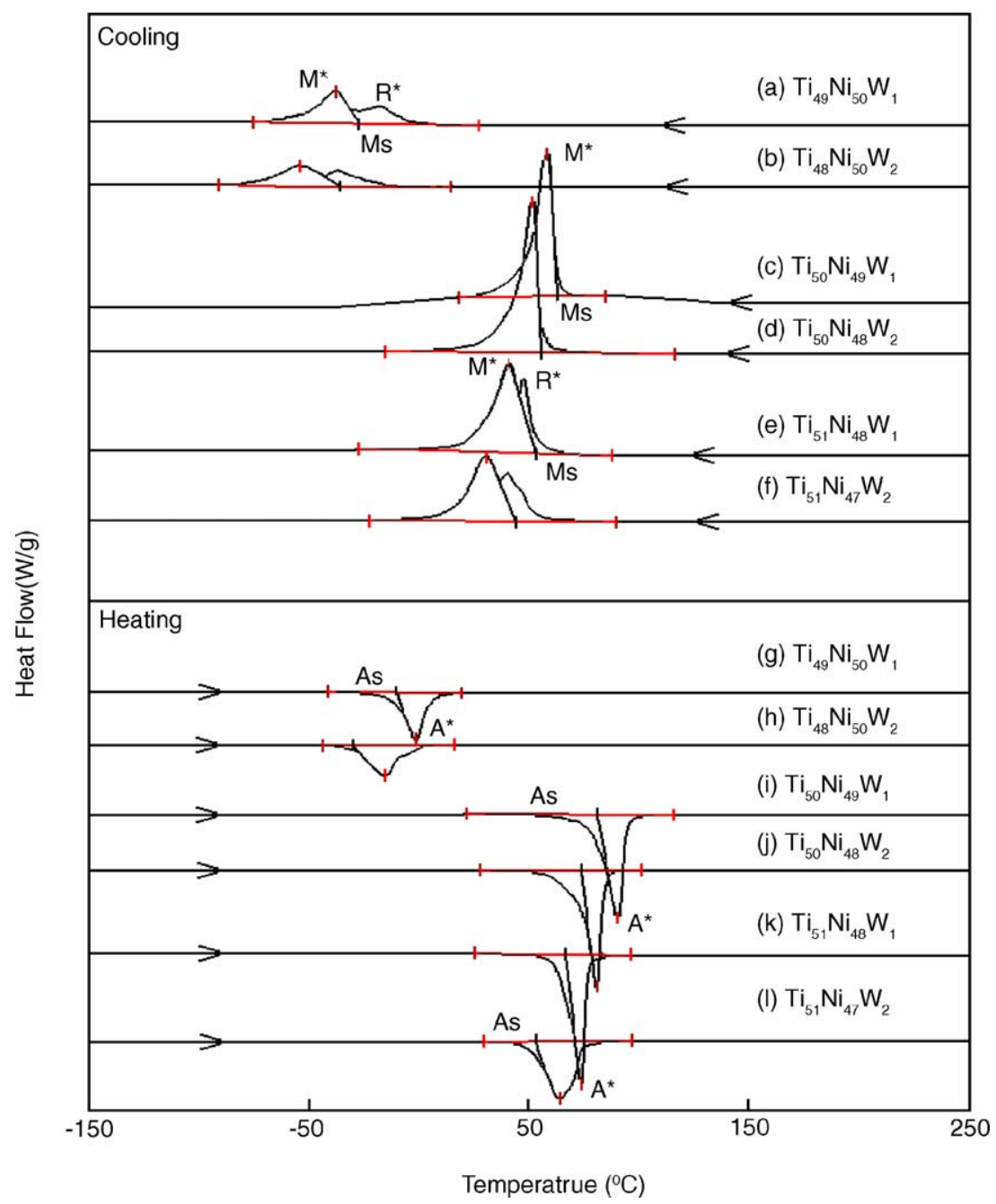

Fig. 3. DSC curves for as-annealed $\mathrm{Ti}_{49} \mathrm{Ni}_{50} \mathrm{~W}_{1}, \mathrm{Ti}_{48} \mathrm{Ni}_{50} \mathrm{~W}_{2}, \mathrm{Ti}_{50} \mathrm{Ni}_{49} \mathrm{~W}_{1}, \mathrm{Ti}_{50} \mathrm{Ni}_{48} \mathrm{~W}_{2}, \mathrm{Ti}_{51} \mathrm{Ni}_{48} \mathrm{~W}_{1}$ and $\mathrm{Ti}_{51} \mathrm{Ni}_{47} \mathrm{~W}_{2}$ alloys on cooling and heating. $\mathrm{M}^{*}$ and $\mathrm{A}^{*}$ are the peak temperatures of forward and reverse martensitic transformation, respectively; and $\mathrm{R}^{*}$ is a peak temperature for premartensitic transformation.

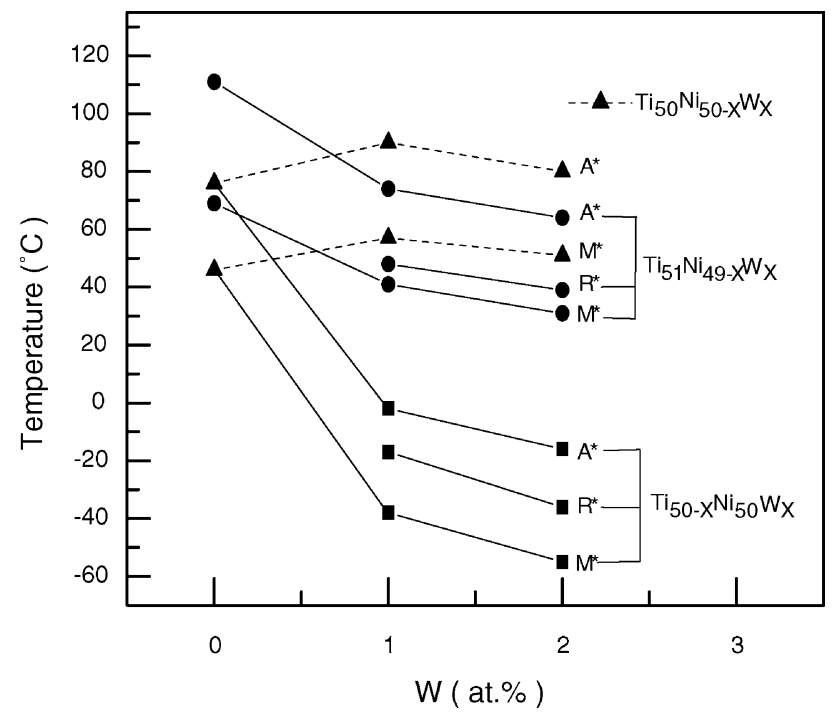

Fig. 4. Transformation temperatures of $\mathrm{M}^{*}, \mathrm{R} *$ and $\mathrm{A} * \mathrm{vs}$. W content for the annealed Ti-Ni-W alloys. increases with increasing matrix hardness, but decreases with increasing amounts of bending strain and second phase. It is reported that the shape recovery of TiNi alloys can be increased by different strengthening/hardening processes $[17,28]$. In other words, if the matrix is strengthened, the slip of dislocations is more difficult than the movement of twin boundaries during the application of external stress. Hence, the permanent plastic strain is reduced and the shape recovery is improved. In the present study, the matrix of TiNi al-

Table 4

The measured shape recovery, $R_{\mathrm{SME}}$, at different bending strain, $\varepsilon_{\mathrm{s}}$, and the volume fraction of second phase particles for $\mathrm{Ti}-\mathrm{Ni}-\mathrm{W}$ specimens

\begin{tabular}{lcll}
\hline \multirow{2}{*}{ TiNiW alloys } & \multicolumn{2}{c}{ Shape recovery, $R_{\text {SME }}(\%)$} & \multirow{2}{*}{ Second phase (vol.\%) } \\
\cline { 2 - 3 } & $\varepsilon_{s}=4 \%$ & $\varepsilon_{s}=8 \%$ & \\
\hline $\mathrm{Ti}_{51} \mathrm{Ni}_{48} \mathrm{~W}_{1}$ & 91.1 & 85.9 & 12 \\
$\mathrm{Ti}_{51} \mathrm{Ni}_{47} \mathrm{~W}_{2}$ & 92.1 & 87.2 & 13 \\
$\mathrm{Ti}_{49} \mathrm{Ni}_{50} \mathrm{~W}_{1}$ & 100 & 97.5 & 3 \\
$\mathrm{Ti}_{48} \mathrm{Ni}_{50} \mathrm{~W}_{2}$ & 100 & 98.6 & 6 \\
\hline
\end{tabular}


loys can be solid-solution strengthened by the addition of 1-2 at.\% W, as shown in Table 3. Hence, the shape recovery is increased. Although the shape recovery is also related to the existence of second phase particles, the effect coming from the volume of second phase particles is much less than that from solid-solution strengthening. For example, as can be seen from Table 4, the volume of second phase particles in $\mathrm{Ti}_{51} \mathrm{Ni}_{47} \mathrm{~W}_{2}$ alloy (about 13\%) and in $\mathrm{Ti}_{51} \mathrm{Ni}_{48} \mathrm{~W}_{1}$ alloy (about 12\%) is almost the same as in $\mathrm{Ti}_{51} \mathrm{Ni}_{49}$ (about $10 \%)$ alloy [15], both $\mathrm{Ti}_{51} \mathrm{Ni}_{47} \mathrm{~W}_{2}(92.1 \%)$ and $\mathrm{Ti}_{51} \mathrm{Ni}_{48} \mathrm{~W}_{1}$ $(91.1 \%)$ have better shape recovery than $\mathrm{Ti}_{51} \mathrm{Ni}_{49}(88 \%)$ [15] since the former two have the harder matrix. Similar results can also be found in annealed $\mathrm{Ti}_{49} \mathrm{Ni}_{50} \mathrm{~W}_{1}$ and $\mathrm{Ti}_{48} \mathrm{Ni}_{50} \mathrm{~W}_{2}$ alloys. Therefore, in Ti-Ni-W SMAs, a higher solid-solution hardness in the matrix will provide better shape recovery.

\section{Conclusion}

In homogenized $\mathrm{Ti}_{50-X} \mathrm{Ni}_{50} \mathrm{~W}_{X}, \mathrm{Ti}_{50} \mathrm{Ni}_{50-X} \mathrm{~W}_{X}$ and $\mathrm{Ti}_{51} \mathrm{Ni}_{49-X} \mathrm{~W}_{X}$ SMAs with $X=1-2$ at.\%, a small amount of $\mathrm{W}$ can be dissolved in the matrix, forming two different second phase particles, $\mathrm{Ti}_{2}(\mathrm{Ni}, \mathrm{W})$ and a tungsten-rich solid solution. DSC test results show that the martensitic transformation sequence of annealed $\mathrm{Ti}_{50-} \mathrm{Ni}_{50} \mathrm{~W}_{X}$ and $\mathrm{Ti}_{51} \mathrm{Ni}_{49-X} \mathrm{~W}_{X}$ alloys with $X=1-2$ at. $\%$ is two-stage B2 $\rightarrow \mathrm{R} \rightarrow \mathrm{B} 19^{\prime}$, but that of $\mathrm{Ti}_{50} \mathrm{Ni}_{50-X} \mathrm{~W}_{X}$ with $X=12$ at. $\%$ is one-stage $\mathrm{B} 2 \rightarrow \mathrm{B} 19^{\prime}$. The transformation peak temperatures of the former-group alloys decrease with increasing $\mathrm{W}$ addition, but those of the latter group are almost identical to those of $\mathrm{Ti}_{50} \mathrm{Ni}_{50}$ alloy. The B19' martensite structure of $\mathrm{Ti}_{50} \mathrm{Ni}_{49} \mathrm{~W}_{1}$ alloy is calculated from the SADPs of TEM as $a=0.301 \mathrm{~nm}, b=0.423 \mathrm{~nm}, c=0.472 \mathrm{~nm}$ and $\beta=97.5^{\circ}$ and these parameters are all larger than those of the binary $\mathrm{Ti}_{50} \mathrm{Ni}_{50}$ alloy. $\mathrm{W}$ is larger than $\mathrm{Ni}$ but smaller than $\mathrm{Ti}$ in atomic size, and is much higher than Ti but not so much higher than Ni in electronegativity. Accordingly, W atoms in $\mathrm{Ti}-\mathrm{Ni}-\mathrm{W}$ SMAs are proposed to replace $\mathrm{Ni}$ atoms, instead of Ti ones. EPMA results for the composition of the matrix and second phase particles also confirm this characteristic. The shape recovery of Ti-Ni-W SMAs can be improved by the $\mathrm{W}$ solid-solution hardening of the matrix. With higher matrix hardness in Ti-Ni-W alloys, there is better shape recovery.

\section{Acknowledgements}

The authors gratefully acknowledge the financial support of this research by the National Science Council (NSC), Republic of China under Grants NSC 91-2216-E151-009 and NSC 92-2216-E002-008.

\section{References}

[1] S. Miyazaki, Y. Igo, K. Otsuka, Acta Metall. 34 (1986) 2045.

[2] S.K. Wu, H.C. Lin, T.S. Chou, Scripta Metall. 23 (1989) 2043.

[3] M. Nishida, T. Honma, Scripta Metall. 18 (1984) 1293.

[4] H.C. Lin, S.K. Wu, T.S. Chou, H.P. Kao, Acta Metall. 39 (1991) 2069.

[5] K.H. Eckelmeyer, Scripta Metall. 10 (1976) 667.

[6] R. Wasilewski, in: J. Perkin (Ed.), Shape Memory Effects in Alloys, Plenum, New York, NY, 1975, p. 245.

[7] C.M. Hwang, M. Meichle, M.B. Salamon, C.M. Wayman, Phil. Mag. 47A (1983) 177.

[8] S.K. Wu, C.M. Wayman, Metallography 20 (1987) 359.

[9] Y.C. Lo, S.K. Wu, C.M. Wayman, Scripta Metall. 24 (1990) 1571.

[10] K. Enami, T. Yoshida, S. Nenno, Proc. ICOMAT-86, The Japan Institute of Metals, Nara, Japan, 1987.

[11] Y.C. Lo, S.K. Wu, H.E. Horng, Acta Metall. Mater. 41 (1993) 747.

[12] T. Nam, T. Saburi, Y. Kawamura, K. Shimizu, Mater. Trans. JIM 31 (1990) 262.

[13] C.S. Zhang, L.C. Zhao, T.W. Duerig, C.M. Wayman, Scritpa Metall. Mater. 24 (1990) 1807.

[14] M. Nishida, C.M. Wayman, T. Honma, Metall. Trans. 17A (1986) 1505.

[15] H.C. Lin, S.K. Wu, J.C. Lin, Mater. Chem. Phys. 37 (1994) 184.

[16] K. Enami, M. Hara, H. Maeda, J. de Physique IV (1995) C8-629.

[17] H.C. Lin, S.K. Wu, Scripta Metall. 26 (1992) 59.

[18] P. Villars, A. Prince, H. Okamoto, Handbook of Ternary Alloy Phase Diagram, vol. 10, ASM International, Pittsburgh, USA, 1995.

[19] K. Otsuka, T. Sawamura, K. Shimizu, Phys. Stat. Sol. 5 (1971) 457.

[20] R.H. Bricknell, K.H. Melton, O. Mercier, Metall. Trans. 10A (1979) 693.

[21] J.P. Schaffer, A. Saxena, S.D. Antolovich, T.H. Sanders Jr., S.B. Warner, The Science and Design of Engineering Materials, second ed., McGraw-Hill, New York, 1999.

[22] S.F. Hsieh, S.K. Wu, J. Mater. Sci. 34 (1999) 1665.

[23] M. Cohen, E.S. Machlin, V.G. Paranjpe, Thermodynamics in Physical Metallurgy., in: American Society for Metals, Metals Park, OH, 1950, p. 242.

[24] E. Hornbogen, Acta Metall. 33 (1985) 595.

[25] S. Eucken, E. Hornbogen, J. Mater. Sci. 19 (1984) 1343.

[26] T. Honma, in: H. Funakubo (Ed.), Shape Memory Alloys, Gordon and Breach, 1984, p. 89.

[27] M. Nishida, C.M. Wayman, Mater. Sci. Eng. 93 (1987) 191.

[28] H.C. Lin, S.K. Wu, Acta Metall. 25 (1991) 1295. 